\title{
Uptake and Storage of Carbon Dioxide in the Ocean: The Global $\mathrm{CO}_{2}$ Survey
}

\author{
Richard A. Feely \\ Pacific Marine and Environmental Laboratory \\ National Oceanic and Atmospheric Administration. Seattle, Washington USA
}

Christopher L. Sabine
University of Washington . Seattle, Washington USA

Taro Takahashi
Lamont-Doherty Earth Observatory . Palisades, New York USA

Rik Wanninkhof

Atlantic Oceanographic and Meteorological Laboratory

National Oceanic and Atmospheric Administration . Miami, Florida USA

\section{Introduction}

Human activity is rapidly changing the composition of the earth's atmosphere, contributing to warming from excess carbon dioxide $\left(\mathrm{CO}_{2}\right)$ along with other trace gases such as water vapor, chlorofluorocarbons, methane and nitrous oxide. These anthropogenic "greenhouse gases" play a critical role in controlling the earth's climate because they increase the infrared opacity of the atmosphere, causing the surface of the planet to warm. The release of $\mathrm{CO}_{2}$ from fossil fuel consumption or the burning of forests for farming or pasture contributes approximately 7 petagrams of carbon ( $1 \mathrm{Pg} \mathrm{C}=1 \times 10^{15} \mathrm{~g} \mathrm{C}$ ) to the atmosphere each year. Approximately $3 \mathrm{Pg} \mathrm{C}$ of this "anthropogenic $\mathrm{CO}_{2}$ " accumulates in the atmosphere annually, and the remaining $4 \mathrm{Pg} \mathrm{C}$ is stored in the terrestrial biosphere and the ocean.

Where and how land and ocean regions vary in their uptake of $\mathrm{CO}_{2}$ from year to year is the subject of much scientific research and debate. Future decisions on regulating emissions of greenhouse gases should be based on more accurate models of the global cycling of carbon and the regional sources and sinks for anthropogenic $\mathrm{CO}_{2}$, models that have been adequately tested against a well-designed system of measurements. The construction of a believable present-day carbon budget is essential for the reliable prediction of changes in atmospheric $\mathrm{CO}_{2}$ and global temperatures from available emissions scenarios.

The ocean plays a critical role in the global carbon cycle as a vast reservoir that exchanges carbon rapidly with the atmosphere, and takes up a substantial portion of anthropogenically-released carbon from the atmosphere. A significant impetus for carbon cycle research over the past several decades has been to achieve a better understanding of the ocean's role as a sink for anthropogenic $\mathrm{CO}_{2}$. There are only three global reservoirs with exchange rates fast enough to vary significantly on the scale of decades to centuries: the atmosphere, the terrestrial biosphere and the ocean. Approximately $93 \%$ of the carbon is located in the ocean, which is able to hold much more carbon than the other reservoirs because most of the $\mathrm{CO}_{2}$ that diffuses into the oceans reacts with seawater to form carbonic acid and its dissociation products, bicarbonate and carbonate ions (Figure 1).

Our present understanding of the temporal and spatial distribution of net $\mathrm{CO}_{2}$ flux into or out of the ocean is derived from a combination of field data, which is limited by sparse temporal and spatial coverage, and model results, which are validated by comparisons with the observed distributions of tracers, including natural carbon-14 $\left({ }^{14} \mathrm{C}\right)$, and anthropogenic chlorofluorocarbons, tritium $\left({ }^{3} \mathrm{H}\right)$ and bomb ${ }^{14} \mathrm{C}$. The latter two radioactive tracers were introduced into the atmosphere-ocean system by atomic testing in the mid $20^{\text {th }}$ century. With additional data from the recent global survey of $\mathrm{CO}_{2}$ in the ocean (1991-1998), carried out cooperatively as part of the Joint Global Ocean Flux Study (JGOFS) and the World Ocean Circulation Experiment (WOCE) Hydrographic Program, it is now possible to characterize in a quantitative way the regional uptake and release of $\mathrm{CO}_{2}$ and its transport in the ocean. In this paper, we summarize our present understanding of the exchange of $\mathrm{CO}_{2}$ across the air-sea 


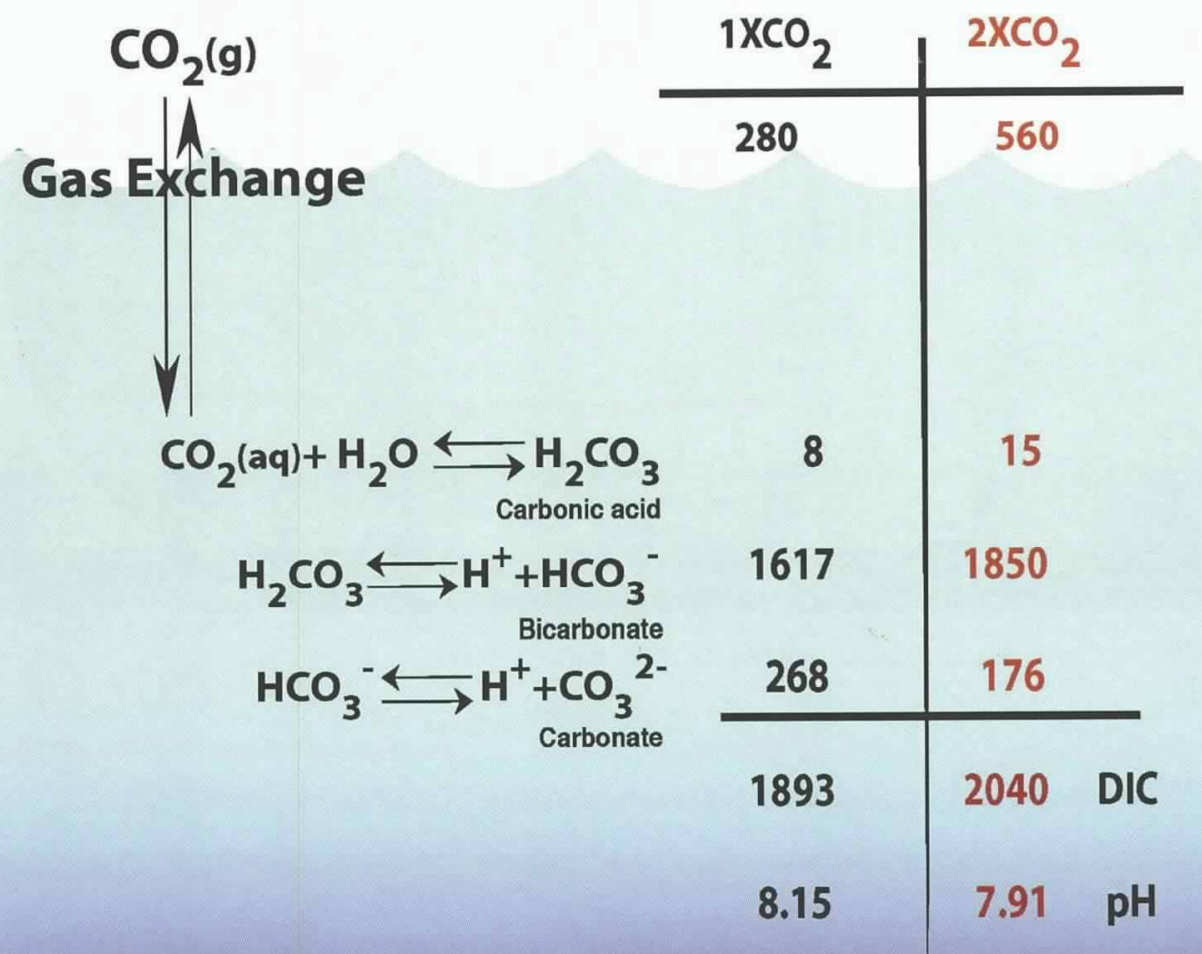

\section{Surface ocean}

Figure 1. Schematic diagram of the carbon dioxide $\left(\mathrm{CO}_{2}\right)$ system in seawater. The $1 \times \mathrm{CO}_{2}$ concentrations are for a surface ocean in equilibrium with a pre-industrial atmospheric $\mathrm{CO}_{2}$ level of $280 \mathrm{ppm}$. The $2 \times \mathrm{CO}_{2}$ concentrations are for a surface ocean in equilibrium with an atmospheric $\mathrm{CO}_{2}$ level of $560 \mathrm{ppm}$. Current model projections indicate that this level could be reached sometime in the second half of this century. The atmospheric values are in units of ppm. The oceanic concentrations, which are for the surface mixed layer, are in units of $\mu \mathrm{mol} \mathrm{kg}^{-1}$.

interface and the storage of natural and anthropogenic $\mathrm{CO}_{2}$ in the ocean's interior.

\section{Background}

The history of large-scale $\mathrm{CO}_{2}$ observations in the ocean date back to the 1970s and 1980s. Measurements of the partial pressure of $\mathrm{CO}_{2}\left(p \mathrm{CO}_{2}\right)$, total dissolved inorganic carbon (DIC) and total alkalinity $\left(\mathrm{A}_{\mathrm{T}}\right)$ were made during the global Geochemical Ocean Sections (GEOSECS) expeditions between 1972 and 1978, the Transient Tracers in the Oceans (TTO) North Atlantic and Tropical Atlantic Surveys in 1981-83, the South Atlantic Ventilation Experiment (SAVE) from 1988-1989, the French Southwest Indian Ocean experiment, and numerous other smaller expeditions in the Pacific and Indian Oceans in the 1980s. These studies provided marine chemists with their first view of the carbon system in the global ocean.
These data were collected at a time when no common reference materials or standards were available. As a result, analytical differences between measurement groups were as large as $29 \mu \mathrm{mol} \mathrm{kg}{ }^{-1}$ for both DIC and $\mathrm{A}_{\mathrm{T}}$, which corresponds to more than $1 \%$ of the ambient values. Large adjustments had to be made for each of the data sets based on deepwater comparisons at nearby stations before individual cruise data could be compared. These differences were often nearly as large as the anthropogenic $\mathrm{CO}_{2}$ signal that investigators were trying to determine (Gruber et al., 1996). Nevertheless, these early data sets made up a component of the surface ocean $p \mathrm{CO}_{2}$ measurements for a global climatology and also provided researchers with new insights into the distribution of anthropogenic $\mathrm{CO}_{2}$ in the ocean, particularly in the Atlantic Ocean.

At the onset of the Global Survey of $\mathrm{CO}_{2}$ in the Ocean (Figure 2), several events took place in the United 




Figure 2. The Global Survey of $\mathrm{CO}_{2}$ in the Ocean: cruise tracks and stations occupied between 1991 and 1998.

States and in international $\mathrm{CO}_{2}$ measurement communities that significantly improved the overall precision and accuracy of the large-scale measurements. In the United States, the $\mathrm{CO}_{2}$ measurement program was co-funded by the Department of Energy (DOE), the National Oceanic and Atmospheric Administration (NOAA) and the National Science Foundation (NSF) under the technical guidance of the U.S. $\mathrm{CO}_{2}$ Survey Science Team. This group of academic and government scientists adopted and perfected the recently developed coulometric titration method for DIC determination that had demonstrated the capability to meet the required goals for precision and accuracy. They advocated the development and distribution of certified reference materials (CRMs) for DIC, and later for $\mathrm{A}_{\mathrm{T}}$, for international distribution under the direction of Andrew Dickson of Scripps Institution of Oceanography (see sidebar). They also supported a shore-based intercomparison experiment under the direction of Charles Keeling, also of Scripps. Through international efforts, the development of protocols for $\mathrm{CO}_{2}$ analyses were adopted for the $\mathrm{CO}_{2}$ survey. The international partnerships fostered by JGOFS resulted in several intercomparison $\mathrm{CO}_{2}$ exercises hosted by France, Japan, Germany and the United States. Through these and other international collaborative programs, the measurement quality of the $\mathrm{CO}_{2}$ survey data was well within the measurement goals of \pm 3 $\mu \mathrm{mol} \mathrm{kg}{ }^{-1}$ and $\pm 5 \mu \mathrm{mol} \mathrm{kg}{ }^{-1}$, respectively, for DIC and $\mathrm{A}_{\mathrm{T}}$.

Several other developments significantly enhanced the quality of the $\mathrm{CO}_{2}$ data sets during this period. New methods were developed for automated underway and discrete $\mathrm{pCO}_{2}$ measurements. An extremely precise method for $\mathrm{pH}$ measurements based on spectrophotometry was also developed by Robert Byrne and his colleagues at the University of South Florida. These improvements ensured that the internal consistency of the carbonate system in seawater could be tested in the field whenever more than two components of the carbonate system were measured at the same location and time. This allowed several investigators to test the overall quality of the global $\mathrm{CO}_{2}$ data set based upon $\mathrm{CO}_{2}$ system thermodynamics. Laboratories all around the world contributed to a very large and internally consistent global ocean $\mathrm{CO}_{2}$ data set determined at roughly $100,000 \mathrm{sam}-$ ple locations in the Atlantic, Pacific, Indian and Southern oceans (Figure 2). The data from the $\mathrm{CO}_{2}$ survey are available through the Carbon Dioxide Information and Analysis Center (CDIAC) at Oak Ridge National Laboratory as Numeric Data Packages and on the World Wide Web (http://cdiac.esd.ornl.gov/home.html). Taro Takahashi and his collaborators have also amassed a large database of surface ocean $p \mathrm{CO}_{2}$ measurements, spanning more than 30 years, into a $p \mathrm{CO}_{2}$ climatology for the global ocean (Takahashi et al., in press). These data have been used to determine the global and regional fluxes for $\mathrm{CO}_{2}$ in the ocean.

\section{$\mathrm{CO}_{2}$ Exchange Across the Air-Sea Interface}

In seawater, $\mathrm{CO}_{2}$ molecules are present in three major forms: the undissociated species in water, $\left[\mathrm{CO}_{2}\right] \mathrm{aq}$, and two ionic species, $\left[\mathrm{HCO}_{3}^{-}\right]$and $\left[\mathrm{CO}_{3}{ }^{2}\right]$ (Figure 1). The concentration of $\left[\mathrm{CO}_{2}\right]$ aq depends upon 


\section{Reference Materials For Oceanic $\mathrm{CO}_{2}$ Measurements}

\section{Andrew G. Dickson}

Scripps Institution of Oceanography

University of California, San Diego,

La Jolla California USA

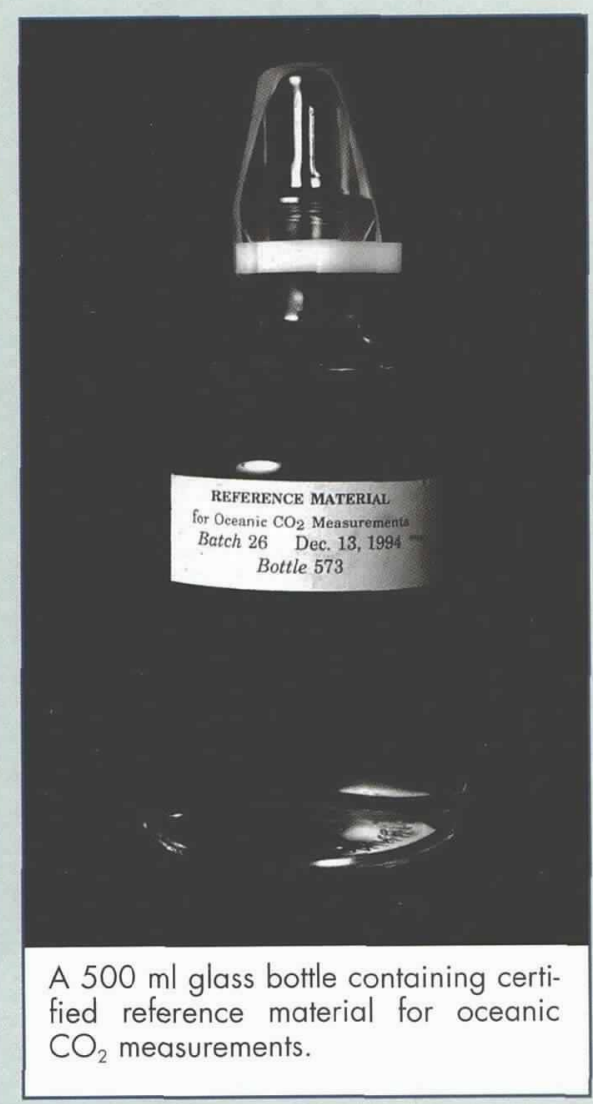

High-quality measurements of carbon dioxide $\left(\mathrm{CO}_{2}\right)$ in the ocean have been an integral part of JGOFS. Despite their importance for understanding the oceanic carbon cycle, measurements made by different groups were rarely comparable in the past. A significant contribution of U.S. JGOFS has been to produce and distribute reference materials for oceanic $\mathrm{CO}_{2}$ measurements. These materials are stable substances for which one or more properties are established sufficiently well to calibrate a chemical analyzer or to validate a measurement process.

Our laboratory at Scripps Institution of Oceanography (SIO), established in 1989 with U.S. JGOFS support from the National Science Foundation (NSF), has prepared over 50 separate batches of reference material and has distributed more than 25,000 bottles of this material to scientists in 33 laboratories in the U.S. and 58 facilities in 24 other countries. The reference materials have been used both as a basis for collaborative studies and as a means of quality control for at-sea measurements. Although most JGOFS field studies are over, we are still distributing more than 2,000 bottles per year and demand is again growing.

To prepare the reference material, we sterilize a batch of seawater, equilibrate it to a virtually constant partial pressure of $\mathrm{CO}_{2}$ and deliver it for bottling. For each batch, surface seawater collected on ships of opportunity and stored in our laboratory is pumped into a holding tank using filters and a sterilizing unit to reduce contamination. When the holding tank is nearly full, mercuric chloride is added as a biocide. The seawater is then recirculated for a few days to ensure complete mixing and enable some gas exchange with filtered air that is pumped through the head-space of the tank. Finally, aliquots of the seawater are pumped through an ultraviolet sterilizing unit and a $0.1 \mathrm{\mu m}$ filter and into clean $500-\mathrm{mL}$ glass bottles. These are sealed with grease and labeled.

Random samples from each batch of reference material are analyzed over a period of 2-3 months for both total dissolved inorganic carbon $\left(C_{T}\right)$ and total alkalinity $\left(A_{T}\right)$, and the results are used to certify the batch before it is distributed. From the start, we used a high-quality method for the determination of $C_{T}$ in which a weighed amount of seawater is acidified and the $\mathrm{CO}_{2}$ extracted under vacuum, purified and determined mano-

metrically. These analyses are carried out in the laboratory of C.D. Keeling at SIO using equipment originally developed for the calibration of gases for atmospheric $\mathrm{CO}_{2}$ measurements.

By 1996, we had also developed an accurate method for the measurement of $A_{T}$ using a two-stage potentiometric, open-cell titration with coulometrically analyzed hydrochloric acid. Once this latter method was being employed routinely to certify new batches of reference material, we used it retrospectively to analyze archived samples from earlier batches.

The uncertainties of these analyses used for certification are $\pm 1.5 \mu \mathrm{mol} \mathrm{kg}^{-1}$ in $C_{T}$ and \pm 2 mol $\mu \mathrm{kg}^{-1}$ in $A_{\text {, }}$, and our reference materials have been shown to be stable for more than 3 years. We are now working on providing $\mathrm{pH}$ values on future reference materials, as well as values for $\delta^{13} \mathrm{C}$.

As part of U.S. JGOFS, the Department of Energy (DOE) supported measurements of



George Anderson filling bottles with sterilized seawater for use as a reference material. 
ocean $\mathrm{CO}_{2}$ system parameters on sections of the WOCE Hydrographic Programme one-time survey. The $\mathrm{CO}_{2}$ Survey Science Team adopted the use of our reference materials as soon as they were available in early 1991 and continued to use them on subsequent cruises. Measurements made on reference materials while at sea were used to ascertain data quality on these expeditions and are thought to have contributed substantially to the overall high quality of the resultant data set.

A further indication that the use of reference materials has improved oceanographic data quality can be seen by examining the degree of agreement between measurements for deep water masses obtained where two separate cruises intersect. For cruises where reference materials were available, measurements of $C_{T}$ in deep water now typically agree to within $2 \mu \mathrm{mol} \mathrm{kg}^{-1}$. This is in sharp contrast to the problems encountered over the years with earlier ocean carbon data sets, where adjustments of as much as 15-20 $\mu \mathrm{mol}$ $\mathrm{kg}^{-1}$ were fairly common. The high-quality data sets now available provide a resource for synthesis and modeling that makes it possible to put together a coherent global view of the oceanic carbon cycle.

\section{Acknowledgements}

This work was supported by NSF through grants OCE8800474, OCE9207265, OCE9521976 and OCE-9819007 and by DOE through Pacific Northwest National Laboratory subcontract No. 121945 and grant DEFG0392ER61410. This work was encouraged early on by Neil Andersen, then at NSF, and has benefited from advice from C.D. Keeling, the members of the $\mathrm{DOE} \mathrm{CO}_{2}$ Survey Science Team and colleagues from the National Oceanic and Atmospheric Administration. I should also like to thank Justine Afghan and George Anderson, who carried out most of the technical work involved in this project, as well as Guy Emanuele and Peter Guenther from the Carbon Dioxide Research Group at SIO, who performed the $C_{T}$ analyses.

the temperature and chemical composition of seawater. The amount of $\left[\mathrm{CO}_{2}\right] \mathrm{aq}$ is proportional to the partial pressure of $\mathrm{CO}_{2}$ exerted by seawater. The difference between the $p \mathrm{CO}_{2}$ in surface seawater and that in the overlying air represents the thermodynamic driving potential for the $\mathrm{CO}_{2}$ transfer across the sea surface. The $p \mathrm{CO}_{2}$ in surface seawater is known to vary geographically and seasonally over a range between about $150 \mu \mathrm{atm}$ and $750 \mu \mathrm{atm}$, or about $60 \%$ below and $100 \%$ above the current atmospheric $p \mathrm{CO}_{2}$ level of about 370 $\mu a t m$. Since the variation of $p \mathrm{CO}_{2}$ in the surface ocean is much greater than the atmospheric $p \mathrm{CO}_{2}$ seasonal variability of about $20 \mu \mathrm{atm}$ in remote uncontaminated marine air, the direction and magnitude of the sea-air $\mathrm{CO}_{2}$ transfer flux are regulated primarily by changes in the oceanic $p \mathrm{CO}_{2}$. The average $p \mathrm{CO}_{2}$ of the global ocean is about $7 \mu \mathrm{atm}$ lower than the atmosphere, which is the primary driving force for uptake by the ocean (see Figure 6 in Karl et al., this issue).

The $p \mathrm{CO}_{2}$ in mixed-layer waters that exchange $\mathrm{CO}_{2}$ directly with the atmosphere is affected primarily by temperature, DIC levels and $\mathrm{A}_{\mathrm{T}}$. While the water temperature is regulated by physical processes, including solar energy input, sea-air heat exchanges and mixedlayer thickness, the DIC and $\mathrm{A}_{\mathrm{T}}$ are primarily controlled by the biological processes of photosynthesis and respiration and by upwelling of subsurface waters rich in respired $\mathrm{CO}_{2}$ and nutrients. In a parcel of seawater with constant chemical composition, $\mathrm{pCO}_{2}$ would increase by a factor of 4 when the water is warmed from polar temperatures of about $-1.9^{\circ} \mathrm{C}$ to equatorial temperatures of about $30^{\circ} \mathrm{C}$. On the other hand, the DIC in the surface ocean varies from an average value of $2150 \mu \mathrm{mol} \mathrm{kg}{ }^{-1}$ in polar regions to 1850 $\mu \mathrm{mol} \mathrm{kg}{ }^{-1}$ in the tropics as a result of biological processes. This change should reduce $p \mathrm{CO}_{2}$ by a factor of 4 . On a global scale, therefore, the magnitude of the effect of biological drawdown on surface water $p \mathrm{CO}_{2}$ is similar in magnitude to the effect of temperature, but the two effects are often compensating. Accordingly, the distribution of $p \mathrm{CO}_{2}$ in surface waters in space and time, and therefore the oceanic uptake and release of $\mathrm{CO}_{2}$, is governed by a balance between the changes in seawater temperature, net biological utilization of $\mathrm{CO}_{2}$ and the upwelling flux of subsurface waters rich in $\mathrm{CO}_{2}$.

\section{Database and Methods}

Surface-water $p \mathrm{CO}_{2}$ has been determined with a high precision ( $\pm 2 \mu \mathrm{atm})$ using underway equilibrator$\mathrm{CO}_{2}$ analyzer systems over the global ocean since the International Geophysical Year of 1956-59. As a result of recent major oceanographic programs, including the global $\mathrm{CO}_{2}$ survey and other international field studies, the database for surface-water $p \mathrm{CO}_{2}$ observations has been improved to about 1 million measurements with several million accompanying measurements of SST, salinity and other necessary parameters such as barometric pressure and atmospheric $\mathrm{CO}_{2}$ concentrations. Based upon these observations, a global, monthly climatological distribution of surface-water $p \mathrm{CO}_{2}$ in the ocean was created for a reference year 1995, chosen because it was the median year of $p \mathrm{CO}_{2}$ observations in the database. The database and the computational method used for interpolation of the data in space and time will be briefly described below.

For the construction of climatological distribution maps, observations made in different years need to be corrected to a single reference year (1995), based on several assumptions explained below (see also Takahashi et al., in press). Surface waters in the subtropical gyres mix vertically at slow rates with subsurface waters because of strong stratification at the base of the mixed 
layer. As a result, they are in contact with the atmosphere and can exchange $\mathrm{CO}_{2}$ for a long time. Consequently, the $p \mathrm{CO}_{2}$ in these warm waters follows the increasing trend of atmospheric $\mathrm{CO}_{2}$ concentrations, as observed by Inoue et al. (1995) in the western North Pacific, by Feely et al. (1999) in the equatorial Pacific and by Bates (2001) near Bermuda in the western North Atlantic. Accordingly, the $p \mathrm{CO}_{2}$ measured in a given month and year is corrected to the same month in the reference year 1995 using the following atmospheric $\mathrm{CO}_{2}$ concentration data for the planetary boundary layer: the GLOBALVIEW- $\mathrm{CO}_{2}$ database (2000) for observations made after 1979 and the Mauna Loa data of Keeling and Whorf (2000) for observations before 1979 (reported in CDIAC NDP-001, revision 7).

In contrast to the waters of the subtropical gyres, surface waters in high-latitude regions are mixed convectively with deep waters during fall and winter, and their $\mathrm{CO}_{2}$ properties tend to remain unchanged from year to year. They reflect those of the deep waters, in which the effect of increased atmospheric $\mathrm{CO}_{2}$ over the time span of the observations is diluted to undetectable levels (Takahashi et al., in press). Thus no correction is necessary for the year of measurements.

\section{Distribution Maps for Climatological Mean Sea-air $\mathrm{pCO}_{2}$ Difference}

Figure 3 shows the distribution of climatological mean sea-air $p \mathrm{CO}_{2}$ difference $\left(\triangle p \mathrm{CO}_{2}\right)$ during February (Figure 3a) and August (Figure 3b) for the reference year 1995. The yellow-red colors indicate oceanic areas where there is a net release of $\mathrm{CO}_{2}$ to the atmosphere, and the blue-purple colors indicate regions where there is a net uptake of $\mathrm{CO}_{2}$. The equatorial Pacific is a strong source of $\mathrm{CO}_{2}$ to the atmosphere throughout the year as a result of the upwelling and vertical mixing of deep waters in the central and eastern regions of the equatorial zone. The intensity of the oceanic release of $\mathrm{CO}_{2}$ decreases westward in spite of warmer temperatures to the west. High levels of $\mathrm{CO}_{2}$ are released in parts of the northwestern subarctic Pacific during the northern winter and the Arabian Sea in the Indian Ocean during August. Strong convective mixing that brings up deep waters rich in $\mathrm{CO}_{2}$ produces the net release of $\mathrm{CO}_{2}$ in the subarctic Pacific. The effect of increased DIC concentration surpasses the cooling effect on $\mathrm{pCO}_{2}$ in seawater during winter. The high $p \mathrm{CO}_{2}$ in the Arabian Sea water is a result of strong upwelling in response to the southwest monsoon. High $p \mathrm{CO}_{2}$ values in these areas are reduced by the intense primary production that follows the periods of upwelling.

The temperate regions of the North Pacific and Atlantic oceans take up a moderate amount of $\mathrm{CO}_{2}$ (blue) during the northern winter (Figure $3 \mathrm{a}$ ) and release a moderate amount (yellow-green) during the northern summer (Figure $3 b$ ). This pattern is the result primarily of seasonal temperature changes. Similar seasonal changes are observed in the southern temperate oceans. Intense regions of $\mathrm{CO}_{2}$ uptake (blue-purple) are seen in the high-latitude northern ocean in summer (Figure 3b) and in the high-latitude South Atlantic and Southern oceans near Antarctica in austral summer (Figure 3a). The uptake is linked to high biological utilization of $\mathrm{CO}_{2}$ in thin mixed layers. As the seasons progress, vertical mixing of deep waters eliminates the uptake of $\mathrm{CO}_{2}$.

These observations point out that the $\Delta p \mathrm{CO}_{2}$ in high-latitude oceans is governed primarily by deepwater upwelling in winter and biological uptake in spring and summer, whereas in the temperate and subtropical oceans, the $\Delta p \mathrm{CO}_{2}$ is governed primarily by water temperature. The seawater $\Delta p \mathrm{CO}_{2}$ is highest during winter in subpolar and polar waters, whereas it is highest during summer in the temperate regions. Thus the seasonal variation of $\triangle p \mathrm{CO}_{2}$ and therefore the shift between net uptake and release of $\mathrm{CO}_{2}$ in subpolar and polar regions is about 6 months out of phase with that in the temperate regions.

The $\Delta p \mathrm{CO}_{2}$ maps are combined with the solubility (s) in seawater and the kinetic forcing function, the gas transfer velocity $(k)$, to produce the flux:

$$
\mathrm{F}=k \bullet s \bullet \Delta p \mathrm{CO}_{2}
$$

The gas transfer velocity is controlled by near-surface turbulence in the liquid boundary layer. Laboratory studies in wind-wave tanks have shown that $k$ is a strong but non-unique function of wind speed. The results from various wind-wave tank investigations and field studies indicate that factors such as fetch, wave direction, atmospheric boundary layer stability and bubble entrainment influence the rate of gas transfer. Also, surfactants can inhibit gas exchange through their damping effect on waves. Since effects other than wind speed have not been well quantified, the processes controlling gas transfer have been parameterized solely with wind speed, in large part because $k$ is strongly dependent on wind, and global and regional wind-speed data are readily available.

Several of the frequently used relationships for the estimation of gas transfer velocity as a function of wind speed are shown in Figure 4 to illustrate their different dependencies. For the Liss and Merlivat (1986) relationship, the slope and intercept of the lower segment was determined from an analytical solution of transfer across a smooth boundary. For the intermediate wind regime, the middle segment was obtained from a field study in a small lake, and results from a wind-wave tank study were used for the high wind regime after applying some adjustments. This relationship is often considered the lower bound of gas transfer-wind speed relationships.

The quadratic relationship of Wanninkhof (1992) was constructed to follow the general shape of curves derived in wind-wave tanks but adjusted so that the global mean transfer velocity corresponds with the long-term global average gas transfer velocity determined from the invasion of bomb ${ }^{14} \mathrm{C}$ into the ocean. Because the bomb ${ }^{14} \mathrm{C}$ is also used as a diagnostic or tun- 


\section{(a) Calculated $\Delta \mathrm{pCO}_{2}$ (Seawater - Air) for February 1995}



(b) Calculated $\quad \mathrm{pCO}_{2}$ (Seawater - Air) for August 1995
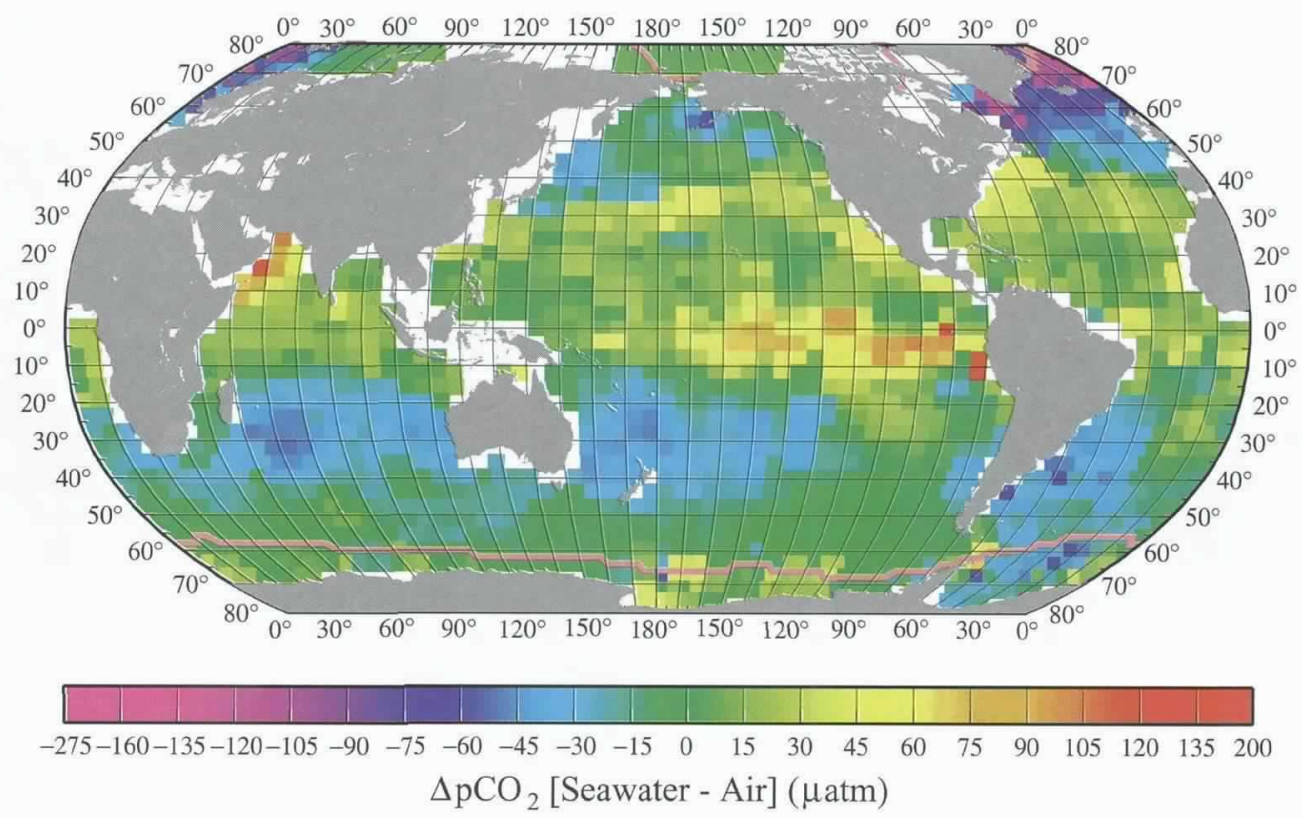

Figure 3. Distribution of climatological mean sea-air $\mathrm{pCO}_{2}$ difference $(\triangle \mathrm{pCO})$ for the reference year 1995 representing nonEl Niño conditions in February (a) and August (b). These maps are based on about 940,000 measurements of surface water $\mathrm{pCO}_{2}$ from 1958 through 2000. The pink lines indicate the edges of ice fields. The yellow-red colors indicate regions with a net release of $\mathrm{CO}_{2}$ into the atmosphere, and the blue-purple colors indicate regions with a net uptake of $\mathrm{CO}_{2}$ from the atmosphere. The mean monthly atmospheric $\mathrm{pCO}_{2}$ value in each pixel in $1995,\left(\mathrm{pCO}_{2}\right)$ air, is computed using $\left(\mathrm{pCO}_{2}\right)$ air $=\left(\mathrm{CO}_{2}\right)$ air $x\left(\mathrm{~Pb}-\mathrm{pH} \mathrm{H}_{2} \mathrm{O}\right) .\left(\mathrm{CO}_{2}\right)$ air is the monthly mean atmospheric $\mathrm{CO}_{2}$ concentration (mole fraction of $\mathrm{CO}_{2}$ in dry air) from the GLOBALVIEW database (2000); $\mathrm{Pb}$ is the climatological mean barometric pressure at sea level from the Atlas of Surface Marine Data (1994); and the water vapor pressure, $\mathrm{pH}_{2} \mathrm{O}$, is computed using the mixed layer water temperature and salinity from the World Ocean Database (1998) of NODC/NOAA. The sea-air $\mathrm{pCO}_{2}$ difference values in the reference year 1995 have been computed by subtracting the mean monthly atmospheric $\mathrm{pCO}_{2}$ value from the mean monthly surface ocean water $\mathrm{pCO}_{2}$ value in each pixel. 


\section{Table 1}

Global oceanic $\mathrm{CO}_{2}$ uptake estimates using different gas exchange-wind speed relationships and different wind speed products ${ }^{\circ}$.

\begin{tabular}{|c|c|c|}
\hline Relationship & Equation & $\begin{array}{l}\text { Flux } \\
\left({\left.\mathrm{Pg} C \mathrm{yr}^{-1}\right)}^{-}\right.\end{array}$ \\
\hline Liss \& Merlivat [1986] & $\begin{array}{l}k=0.17 U_{10}\left(U_{10}<3.6 \mathrm{~m} \mathrm{~s}^{-1}\right) \\
k=2.85 U_{10}-9.65\left(3.6 \mathrm{~m} \mathrm{~s}^{-1}<U_{10}<13 \mathrm{~m} \mathrm{~s}^{-1}\right) \\
k=5.9 U_{10}-49.3\left(U_{10}>13 \mathrm{~m} \mathrm{~s}^{-1}\right)\end{array}$ & -1.0 \\
\hline Wanninkhof [1992] [W-92] & $k=0.39 \mathrm{U}_{10}^{2} \quad$ (long term averaged winds) & -1.8 \\
\hline $\begin{array}{l}\text { Wanninkhof \& McGillis (1999) } \\
\text { [W\&M-99] }\end{array}$ & $\begin{array}{l}k=1.09 U_{10}-0.333 U_{10^{2}}+0.078 U_{10}^{3} \\
\text { (long term averaged winds) }\end{array}$ & -3.0 \\
\hline Nightingale et al. [2000] & $k=0.333 U_{10}+0.222 U_{10}^{2}$ & -1.5 \\
\hline $\begin{array}{l}\text { NCEP-41 year average winds }{ }^{b} \\
\text { [W-92] }\end{array}$ & $k=0.39 U_{10}^{2}$ (long term averaged winds) & -2.2 \\
\hline NCEP 6-hour winds ${ }^{c}$ & $\mathrm{k}=0.31 \mathrm{U}_{10}{ }^{2}$ (instantaneous winds) $[\mathrm{W}-92]$ & -1.7 \\
\hline NCEP 6-hours winds ${ }^{c}$ & $k=0.0283 U_{10}{ }^{3}[W \& M-99]$ & -2.3 \\
\hline \multicolumn{3}{|c|}{$\begin{array}{l}\text { a: For these calculations the monthly } \triangle \mathrm{pCO}_{2} \text { climatology of Takahashi et al. (in press) was used } \\
\text { according to: } \mathrm{F}=k(\mathrm{Sc} / 660)^{-1 / 2} \mathrm{~s} \Delta \mathrm{pCO}_{2} \text {, Sc is the Schmidt number, which is determined for each } \\
\text { pixel from climatological SST. The solubility s was determined from standard relationships with } \\
\text { SST and salinity. Unless noted, the monthly mean NCEP wind speeds for } 1995 \text { were used. }\end{array}$} \\
\hline \multicolumn{3}{|c|}{ b: Using the NCEP 41 -year average monthly wind speed product rather than that of 1995 . } \\
\hline $\begin{array}{l}\text { c: Using the NCEP 6-hour wi } \\
\text { of W-92 and W\&M-99 we }\end{array}$ & oduct. In these cases, the instantaneous wind sp & formu \\
\hline
\end{tabular}

ing parameter in global ocean biogeochemical circulation models, this parameterization yields internally consistent results when used with these models, making it one of the more favored parameterizations.

Using the same longterm global ${ }^{14} \mathrm{C}$ constraint but basing the general shape of the curve on recent $\mathrm{CO}_{2}$ flux observations over the North Atlantic determined using the covariance technique, Wanninkhof and McGillis (1999) proposed a significantly stronger (cubic) dependence with wind speed. This relationship shows a weaker dependence on wind for wind speeds less than $10 \mathrm{~ms}^{-1}$ and a significantly stronger dependence at higher wind speeds. However, the relationship is not well constrained at high wind speeds because of the large scatter in the scarce observations. Both the $U^{2}$ and $U^{3}$ relationships fit within the data envelope of the study, but the $\mathrm{U}^{3}$ relationship provides a significantly better fit. Nightingale et al. (2000) determined a gas exchange-wind speed relationship based on the results of a series of experiments utilizing deliberately injected sulfur hexafluoride $\left(\mathrm{SF}_{6}\right)$, ${ }^{3} \mathrm{He}$ and non-volatile tracers performed in the last decade.

The global oceanic $\mathrm{CO}_{2}$ uptake using different wind speed/gas transfer velocity parameterizations differs by a factor of three (Table 1). The wide range of global $\mathrm{CO}_{2}$ fluxes for the different relationships illustrates the large range of results and assumptions that are used to produce these relationships. Aside from differences in global oceanic $\mathrm{CO}_{2}$ uptake, there are also significant regional differences. Figure 5 shows that the relationship of W\&M-99 yields systematically lower evasion rates in the equatorial region and higher uptake rates at high latitudes compared with W-92, leading to significantly larger global $\mathrm{CO}_{2}$ uptake estimates.

In addition to the non-unique dependence of gas exchange on wind speed, which causes a large spread in global air-sea $\mathrm{CO}_{2}$ flux estimates, there are several other factors contributing to biases in the results. Global wind-speed data obtained from shipboard observations, satellites and data assimilation techniques show significant differences on regional and global scales. Because of the non-linearity of the relationships between gas exchange and wind speed, significant biases are introduced in methods of averaging 




Figure 5. Effects of the various gas transfer/wind speed relationships on the estimated air-sea exchange flux of $\mathrm{CO}_{2}$ in the ocean as a function of latitude. The global effects on the net air-sea flux are given in Table 1.

the product of gas transfer velocity and wind speed. The common approach of averaging the $\Delta p \mathrm{CO}_{2}$ and $k$ separately over monthly periods, determining the flux from the product and ignoring the cross product leads to a bias that is about 0.2 to $0.8 \mathrm{Pg}$. C yr ${ }^{-1}$ lower in the global uptake estimate. This bias shows a regional variation that is dependent on the distribution and magnitude of winds. This issue has been partly rectified in some of the relationships in which a global wind-speed distribution is used to create separate relationships between gas transfer and wind speed for short-term (a day or less) and long-term (a month or more) periods. Since wind-speed distributions are regionally dependent and vary on time scales of hours, this approach is far from perfect.

The groundwork of efforts laid over the past decade and recently improved technologies make the quantification of regional and global $\mathrm{CO}_{2}$ fluxes a more tractable problem now. Satellites equipped with scatterometers that are used to determine wind speed offer daily global coverage. Moreover, these instruments measure sea-surface roughness that is directly related to gas transfer. This remotely sensed information, along with regional statistics of wind-speed variability on time scales shorter than a day, offers the real possibility that more accurate gas transfer velocities will be obtained. Efforts are underway to increase the coverage of $p \mathrm{CO}_{2}$ through more frequent measurements and data assimilation techniques, again utilizing remote sensing of parameters such as sea-surface temperature and wind speed. Better quantification of the fluxes will lead to better boundary conditions for models and improved forecasts of atmospheric $\mathrm{CO}_{2}$ concentrations.

\section{Distribution of the Climatological Mean Net Sea-air $\mathrm{CO}_{2}$ Flux}

To illustrate the sensitivity of the gas transfer velocity and thus the sea-air $\mathrm{CO}_{2}$ flux to wind speed, we have estimated the regional and global net sea-air $\mathrm{CO}_{2}$ fluxes using two different formulations for the $\mathrm{CO}_{2}$ gas transfer coefficient across the sea-air interface: the quadratic $\mathrm{U}^{2}$ dependence of $\mathrm{W}-92$ and the cubic $\mathrm{U}^{3}$ dependence of W\&M-99. In addition, we have demonstrated the effects of wind-speed fields on the computed sea-air $\mathrm{CO}_{2}$ flux using the National Center for Environmental Prediction (NCEP)-41 mean monthly wind speed and the NCEP1995 mean monthly wind speed distributions over $4^{\circ} \mathrm{x}$ $5^{\circ}$ pixel areas.

In Table 2 the fluxes computed using the $\mathrm{W}-92$ and the NCEP/National Center for Atmospheric Research (NCAR) 41-year mean wind are listed in the first row for each grouping in column one (for latitudinal bands, oceanic regions and regional flux). The column "Errors in Flux" located at the extreme right of Table 2 lists the deviations from the mean flux that have been determined by adding or subtracting one standard deviation of the wind speed (about $\pm 2 \mathrm{~m} \mathrm{sec}^{-1}$ on the global average) from the mean monthly wind speed in each pixel area. These changes in wind speeds affect the regional and global flux values by about $\pm 25 \%$. The fluxes computed using the single year mean wind speed data for 1995 are listed in the second line in each column one grouping in the table.

The global ocean uptake estimated using the W-92 and the NCEP 41-yr mean wind speeds is $-2.2 \pm 0.4 \mathrm{Pg}$ $\mathrm{C} \mathrm{yr}^{-1}$. This is consistent with the ocean uptake flux of $-2.0 \pm 0.6$ Pg C yr ${ }^{-1}$ during the 1990s (Keeling et al., 1996; Battle et al., 2000) estimated from observed changes in the atmospheric $\mathrm{CO}_{2}$ and oxygen variations.

The wind speeds for 1995 are much lower than the 41-year mean in the northern hemisphere and higher over the Southern Ocean. Accordingly, the northern ocean uptake of $\mathrm{CO}_{2}$ is weaker than the climatological mean, and the Southern Ocean uptake is stronger. The global mean ocean uptake flux of $-1.8 \mathrm{Pg} \mathrm{C} \mathrm{yr}^{-1}$ using the NCEP-1995 winds is about $18 \%$ below the climatological mean of $-2.2 \mathrm{Pg} \mathrm{C} \mathrm{yr}^{-1}$, but it is within the $\pm 25 \%$ error estimated from the standard deviation of the 41-yr mean wind speed data.

When the cubic wind speed dependence (W\&M-99) is used, the $\mathrm{CO}_{2}$ fluxes in higher latitude areas with strong winds are increased by about $50 \%$, as are the errors associated with wind speed variability. The global ocean uptake flux computed with the 41-year mean wind speed data and the NCEP-1995 wind data is -3.7 $\mathrm{Pg} \mathrm{C} \mathrm{yr}^{-1}$ and $-3.0 \mathrm{PgC} \mathrm{yr}^{-1}$ respectively, an increase of about $70 \%$ over the fluxes computed from the W-92 dependence. These flux values are significantly greater than the flux based on atmospheric $\mathrm{CO}_{2}$ and oxygen data (Keeling et al., 1996; Battle et al., 2000). However, the relative magnitudes of $\mathrm{CO}_{2}$ uptake by ocean basins (shown in \% in the regional flux grouping in the last four rows of Table 2) remain nearly unaffected by the 
choice of the wind-speed dependence of the gas transfer velocity.

The distribution of winds can also influence the calculated gas transfer velocity. This is because of the nonlinear dependence of gas exchange with wind speed; long-term average winds underestimate flux especially for strongly non-linear dependencies. To avoid this bias, the relationships are adjusted by assuming that the global average wind speed is well represented by a Rayleigh distribution function. As noted by Wanninkhof et al. (in press), this overestimates the flux. A more appropriate way to deal with the issue of wind speed variability is to use short-term winds. If the NCEP 6-hour wind products are used, the global flux computed using the W\&M-99 cubic wind-speed formulation decreases from -3.7 to -3.0 Pg C yr ${ }^{-1}$ for the NCEP 41-year winds and from -3.0 to $-2.3 \mathrm{Pg} \mathrm{C} \mathrm{yr}^{-1}$ for the NCEP 1995 wind data.

The relative importance of the major ocean basins in the ocean uptake of $\mathrm{CO}_{2}$ may be assessed on the basis of the $\mathrm{CO}_{2}$ fluxes obtained from our $p \mathrm{CO}_{2}$ data and W-92 gas transfer velocity (Table 2 and Figure 6). The Atlantic Ocean as a whole, which has $23.5 \%$ of the global ocean area, is the region with the strongest net $\mathrm{CO}_{2}$ uptake $(41 \%)$. The high-latitude northern North Atlantic, including the Greenland, Iceland and Norwegian seas, is responsible for a substantial amount of this $\mathrm{CO}_{2}$ uptake while representing only $5 \%$ of the global ocean in area. This reflects a combination of two factors: the intense summertime primary production and the low $\mathrm{CO}_{2}$ concentrations in subsurface waters associated with recent ventilation of North Atlantic subsurface waters. The Pacific Ocean as a whole takes up the smallest amount of $\mathrm{CO}_{2}(18 \%$ of the total) in spite of its size ( $49 \%$ of the total ocean area). This is because mid-latitude one standard deviation. uptake (about 1.1 $\mathrm{Pg} \mathrm{C} \mathrm{yr}^{-1}$ ) is almost compensated for by the large equatorial release of about $0.7 \mathrm{Pg} \mathrm{C} \mathrm{yr}^{-1}$. If the equatorial flux were totally eliminated, as during very strong El Niño conditions, the Pacific would take up $\mathrm{CO}_{2}$ to an extent comparable to the entire North and South Atlantic Ocean. The southern Indian Ocean is a region of strong uptake in spite of its small area $(15 \%$ of the total). This may be attributed primarily to the cooling of tropical waters flowing southward in the western South Indian Ocean.

\section{Table 2}

The effects of wind speeds and the wind-speed dependence of $\mathrm{CO}_{2}$ gas transfer velocity on the net sea-air $\mathrm{CO}_{2}$ flux are shown using the climatological sea-air $\mathrm{pCO}_{2}$ difference obtained in this work. The flux values have been computed using the (wind speed) ${ }^{2}$ dependence of $\mathrm{CO}_{2}$ gas transfer velocity by Wanninkhof (1992, W-92) and the (wind speed) ${ }^{3}$ dependence by Wanninkhof and McGillis (1999, W\&M-99) respectively for each of the two sets of wind data: the NCEP/NCAR 41-year (named 41-yr in the table) and 1995 mean monthly wind speeds. Errors in flux (\% in the flux) listed in the extreme right column represent the flux changes resulting from + or - one standard deviation (about $+2 \mathrm{~m} \mathrm{sec}^{-1}$ on the global average) from the annual mean wind speed in each pixel area. The positive errors in the flux represent an increase in the mean monthly wind speed over each pixel area by one standard deviation; and the negative errors represent a reduction of the mean wind speed by

\begin{tabular}{|c|c|c|c|c|c|c|c|}
\hline Lat. Band & $\begin{array}{l}\text { Gas Trans./ } \\
\text { Wind Data }\end{array}$ & $\begin{array}{l}\text { Pacific } \\
\text { Ocean }\end{array}$ & $\begin{array}{l}\text { Atlantic } \\
\text { Ocean }\end{array}$ & $\begin{array}{l}\text { Indian } \\
\text { Ocean }\end{array}$ & $\begin{array}{l}\text { Southern } \\
\text { Ocean }\end{array}$ & $\begin{array}{l}\text { Global } \\
\text { Ocean }\end{array}$ & $\begin{array}{l}\text { Errors in } \\
\text { Flux }\end{array}$ \\
\hline 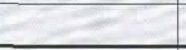 & & $\mathrm{Pg} C_{y r^{-1}}$ & $\mathrm{Pg} C \mathrm{yr}^{-1}$ & $\mathrm{Pg} \mathrm{yr}^{-1}$ & $\mathrm{Pg} \mathrm{C}_{\mathrm{yr}^{-1}}$ & $\mathrm{PgC}_{\mathrm{yr}} \mathrm{r}^{-1}$ & $0 / 0$ \\
\hline \multirow[t]{4}{*}{$\mathrm{N}$ of $50^{\circ} \mathrm{N}$} & W-92/41-yr & +0.01 & -0.40 & $\ldots \ldots$ & $\ldots \ldots$ & -0.39 & $+28 \%,-23 \%$ \\
\hline & W-92/1995 & +0.03 & -0.18 & $\ldots \ldots$ & $\ldots \ldots$ & -0.14 & \\
\hline & $W \& M-99 / 41-y r$ & +0.03 & -0.55 & $\ldots \ldots$ & $\ldots \ldots$ & -0.52 & $+44 \%,-35 \%$ \\
\hline & W\&M-99/1995 & +0.07 & -0.17 & $\ldots \ldots$ & $\ldots \ldots$ & -0.10 & +2 \\
\hline \multirow{2}{*}{$14^{\circ} \mathrm{N}-50^{\circ} \mathrm{N}$} & $W-92 / 41-y r$ & -0.64 & -0.34 & +0.07 & $\ldots$. & -0.92 & $+25 \%,-23 \%$ \\
\hline & W-92/1995 & -0.29 & -0.28 & +0.03 & ....... & -0.54 & 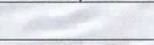 \\
\hline \multirow{2}{*}{  } & $W \& M-99 / 41-y r$ & -0.94 & -0.48 & +0.10 & $\ldots \ldots$ & -1.31 & $+43 \%,-32 \%$ \\
\hline & W\&M-99/1995 & -0.29 & -0.38 & +0.02 & $\ldots \ldots$ & -0.64 & \\
\hline \multirow[t]{2}{*}{$14^{\circ} \mathrm{N}-14^{\circ} \mathrm{S}$} & W-92/41-yr & +0.74 & +0.15 & +0.18 & $\ldots \ldots$ & +1.07 & $+29 \%,-24 \%$ \\
\hline & W-92/1995 & +0.61 & +0.07 & +0.15 & $\ldots \ldots$ & +0.83 & \\
\hline \multirow{2}{*}{ 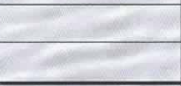 } & $W \& M-99 / 41-y r$ & +0.67 & +0.14 & +0.20 & $\ldots \ldots$ & +1.00 & $+43 \%,-31 \%$ \\
\hline & W\&M-99/1995 & +0.62 & +0.05 & +0.12 & $\ldots \ldots$ & +0.79 & 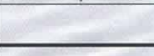 \\
\hline \multirow{4}{*}{$14^{\circ} \mathrm{S}-50^{\circ} \mathrm{S}$} & $W-92 / 41-y r$ & -0.51 & -0.33 & -0.67 & ....... & -1.51 & $+22 \%,-20 \%$ \\
\hline & W-92/1995 & -0.57 & -0.31 & -0.50 & $\ldots \ldots$ & -1.38 & \\
\hline & $W \& M-99 / 41-y r$ & -0.68 & -0.51 & -0.97 & $\ldots \ldots$ & -2.16 & $+37 \%,-30 \%$ \\
\hline & W\&M-99/1995 & -0.88 & -0.51 & -0.63 & $\ldots \ldots$ & -2.02 & \\
\hline \multirow{2}{*}{$\mathrm{S}$ of $50^{\circ} \mathrm{S}$} & $w-92 / 41-y r$ & ....... & $\ldots \ldots$ & ...... & -0.47 & -0.47 & $+26 \%,-21 \%$ \\
\hline & W-92/1995 & $\ldots \ldots$ & $\ldots \ldots$ & $\ldots \ldots$ & -0.58 & -0.58 & \\
\hline \multirow{2}{*}{+2} & W\&M-99/41-yr & $\ldots \ldots$ & $\ldots \ldots$ & $\ldots \ldots$ & -0.74 & -0.74 & $+41 \%,-32 \%$ \\
\hline & W\&M-99/1995 & $\ldots \ldots$ & & $\ldots \ldots$ & -1.02 & -1.02 & \\
\hline $\begin{array}{ll}-\cdots \\
-\cdots+\end{array}$ & 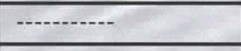 & \begin{tabular}{|l|}
$-\cdots+\cdots$ \\
\end{tabular} & \begin{tabular}{|l|}
$-\cdots+$ \\
$-\cdots+$
\end{tabular} & $\begin{array}{ll}-\cdots+ \\
-\cdots+\end{array}$ & $\begin{array}{ll}+\cdots \\
\cdots+-1\end{array}$ & \begin{tabular}{|l|}
$-\mathrm{N}$ \\
\end{tabular} & \\
\hline \multirow{4}{*}{\begin{tabular}{l|} 
Oceanic \\
Regions \\
\end{tabular}} & $W-92 / 41-y r$ & -0.40 & -0.92 & -0.43 & -0.47 & -2.22 & $+22 \%,-19 \%$ \\
\hline & W-92/1995 & -0.21 & -0.69 & -0.33 & -0.58 & -1.81 & \\
\hline & $W \& M-99 / 41-y r$ & -0.92 & -1.39 & -0.67 & -0.74 & -3.72 & $+40 \%,-32 \%$ \\
\hline & W\&M-99/1995 & -0.48 & -1.01 & -0.48 & -1.02 & -3.00 & \\
\hline \multirow{4}{*}{$\begin{array}{l}\text { Regional } \\
\text { Flux }(\%)\end{array}$} & $W-92 / 41-y r$ & 18 & 41 & 19 & 21 & 100 & \\
\hline & W-92/1995 & 12 & 38 & 18 & 32 & 100 & \\
\hline & $W \& M-99 / 41-y r$ & 25 & 37 & 18 & 20 & 100 & \\
\hline & W\&M-99/1995 & 16 & 34 & 16 & 34 & 100 & \\
\hline
\end{tabular}




\section{Mean Annual Air-Sea Flux for 1995}
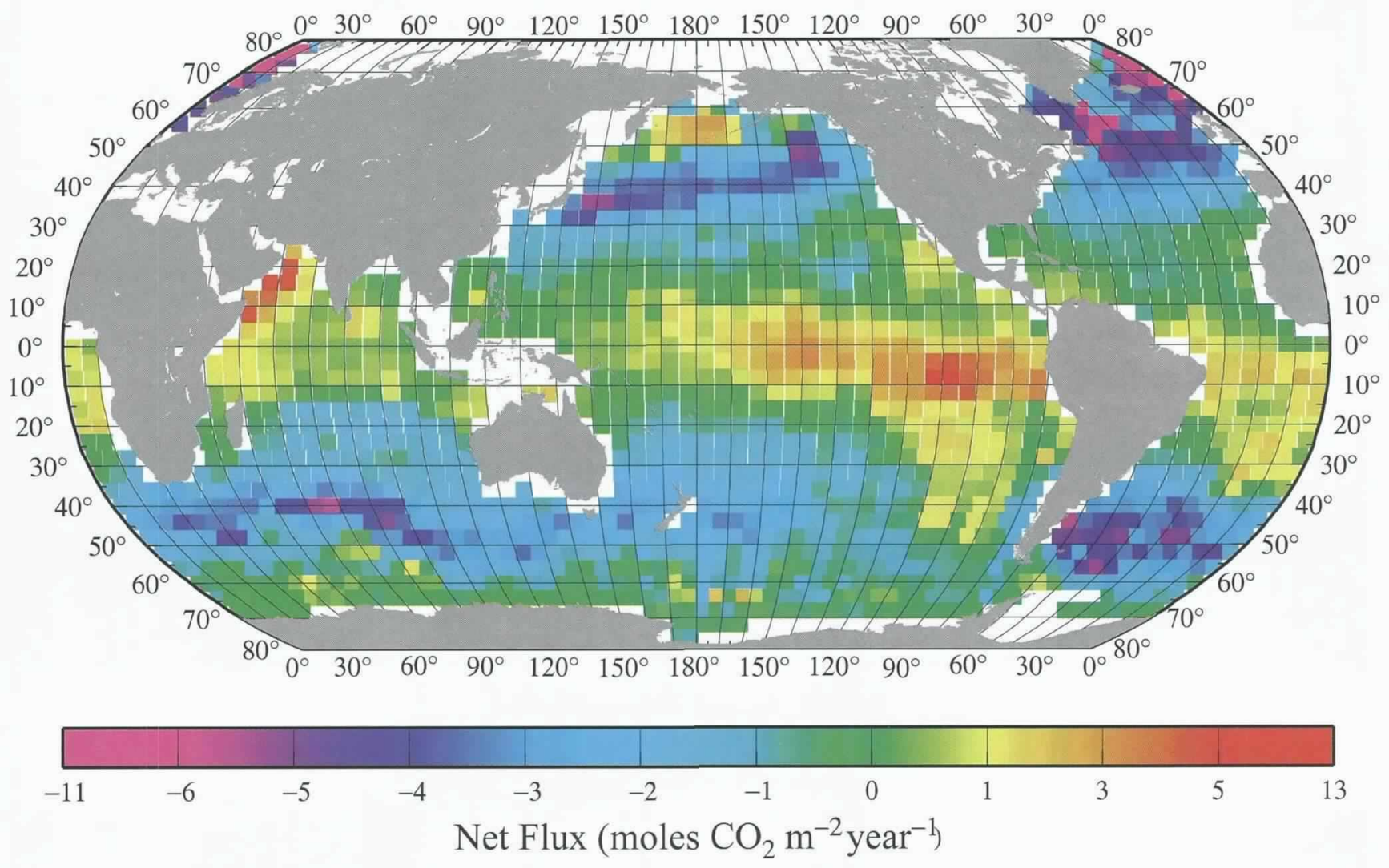

Figure 6. Distribution of the climatological mean annual sea-air $\mathrm{CO}_{2}$ flux (moles $\mathrm{CO}_{2} \mathrm{~m}^{-2} \mathrm{yr} \mathrm{r}^{-1}$ ) for the reference year 1995 representing non-El Niño conditions. This has been computed using the mean monthly distribution of sea-air $\mathrm{pCO}_{2}$ difference, the climatological NCEP 41-year mean wind speed and the wind-speed dependence of the $\mathrm{CO}_{2}$ gas transfer velocity of Wanninkhof (1992). The yellow-red colors indicate a region characterized by a net release of $\mathrm{CO}_{2}$ to the atmosphere, and the blue-purple colors indicate a region with a net uptake of $\mathrm{CO}_{2}$ from the atmosphere. This map yields an annual oceanic uptake flux for $\mathrm{CO}_{2}$ of $2.2 \pm 0.4 \mathrm{PgC} \mathrm{yr}^{-1}$.

\section{Distribution of Anthropogenic $\mathrm{CO}_{2}$ in the Oceans}

To understand the role of the oceans as a sink for anthropogenic $\mathrm{CO}_{2}$, it is important to determine the distribution of carbon species in the ocean interior and the processes affecting the transport and storage of $\mathrm{CO}_{2}$ taken up from the atmosphere. Figure 7 shows the typical north-south distribution of DIC in the Atlantic, Indian, and Pacific oceans prior to the introduction of anthropogenic $\mathrm{CO}_{2}$. In general, DIC is about $10-15 \%$ higher in deep waters than at the surface. Concentrations are also generally lower in the Atlantic than the Indian ocean, with the highest concentrations found in the older deep waters of the North Pacific. The two basic mechanisms that control the distribution of carbon in the oceans are the solubility and biological pumps.

The solubility pump is driven by two interrelated factors. First, $\mathrm{CO}_{2}$ is more than twice as soluble in cold polar waters than in warm equatorial waters. As western surface boundary currents transport water from the tropics to the poles, the waters are cooled and absorb more $\mathrm{CO}_{2}$ from the atmosphere. Second, the high-latitude zones are also regions where intermediate and bottom waters are formed. As these waters cool, they become denser and sink into the ocean interior, taking with them the $\mathrm{CO}_{2}$ accumulated at the surface.

The primary production of marine phytoplankton transforms $\mathrm{CO}_{2}$ and nutrients from seawater into organic material. Although most of the $\mathrm{CO}_{2}$ taken up by phytoplankton is recycled near the surface, a substantial fraction, perhaps $30 \%$, sinks into the deeper waters before being converted back into $\mathrm{CO}_{2}$ by marine bacteria. Only about $0.1 \%$ reaches the seafloor to be buried in the sediments. The $\mathrm{CO}_{2}$ that is recycled at depth is slowly transported over long distances by the largescale thermohaline circulation. DIC slowly accumulates 


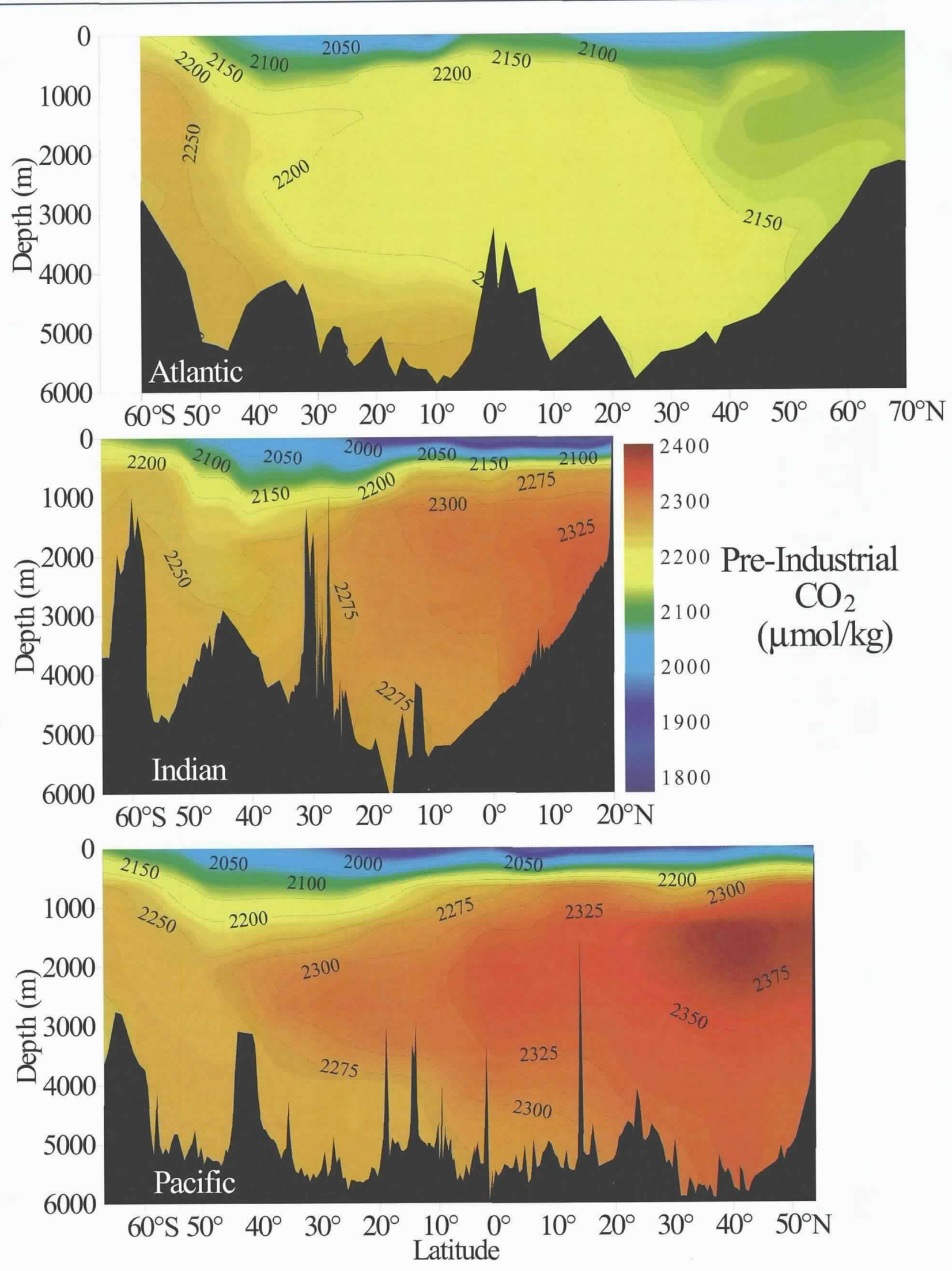

Figure 7. Zonal mean pre-industrial distributions of dissolved inorganic carbon (in units of $\mu$ mol $\mathrm{kg}^{-1}$ ) along north-south transects in the Atlantic, Indian and Pacific oceans. The Pacific and Indian Ocean data are from the Global $\mathrm{CO}_{2}$ Survey (this study), and the Atlantic Ocean data are from Gruber (1998). 
in the deep waters as they travel from the Atlantic to the Indian and Pacific oceans. Using a 3-D global carbon model, Sarmiento et al. (1995) estimated that the natural solubility pump is responsible for about $20 \%$ of the vertical gradient in DIC; the remaining $80 \%$ originates from the biological pump.

The approaches for estimating anthropogenic $\mathrm{CO}_{2}$ in the oceans have taken many turns over the past decade. Siegenthaler and Sarmiento (1993) summarized early approaches for estimating the anthropogenic sink in the oceans, including ocean models of various complexity, atmospheric measurements and transport models used together with $p \mathrm{CO}_{2}$ measurements and estimates based on changes in oceanic ${ }^{13} \mathrm{C}$ and oxygen mass balance. They noted the wide range of ocean uptake estimates $\left(1.6-2.3 \mathrm{PgC} \mathrm{yr}^{-1}\right)$ and concluded that the larger uptake estimates from the models were the most reliable.

The first approaches for using measurements to isolate anthropogenic $\mathrm{CO}_{2}$ from the large, natural DIC signal were independently proposed by Brewer (1978) and Chen and Millero (1979). Both these approaches were based on the premise that the anthropogenic DIC concentration could be isolated from the measured DIC by subtracting the contributions of the biological pump and the physical processes, including the pre-industrial source water values and the solubility pump.

Gruber et al. (1996) improved the earlier approaches by developing the $\Delta C^{*}$ method. This method is based on the premise that the anthropogenic $\mathrm{CO}_{2}$ concentration $\left(\mathrm{C}^{\text {ant }}\right)$ can be isolated from measured DIC values $\left(\mathrm{C}^{\mathrm{m}}\right)$ by subtracting the contribution of the biological pumps ( $\Delta C^{\text {bro }}$ ), the DIC the waters would have in equilibrium with a preindustrial atmospheric $\mathrm{CO}_{2}$ concentration of $280 \mathrm{ppm}\left(\mathrm{C}^{\mathrm{eq} 207}\right)$, and a term that corrects for the fact that surface waters are not always in equilibrium with the atmosphere $\left(\Delta C^{\text {disca }}\right)$ :

$$
C^{\text {ant }}=C^{\mathrm{m}}-\Delta C^{\text {bro }}-C^{\text {eq288n }}-C^{\text {dseq }}=\Delta C^{*}-\Delta C^{\text {dise? }} .
$$

The three terms to the right of the first equal sign make up $\Delta C^{*}$, which can be explicitly calculated for each sample. The fact that $\Delta \mathrm{C}^{*}$ is a quasi-conservative tracer helps remedy some of the mixing concerns arising from the earlier techniques (Sabine and Feely, 2001). The $\Delta C^{\text {discy }}$ term is evaluated over small isopycnal intervals using a water-mass age tracer such as CFCs.

We have evaluated anthropogenic $\mathrm{CO}_{2}$ for the Atlantic, Indian, and Pacific oceans using the $\Delta C^{*}$ approach. Figure 8 shows representative sections of anthropogenic $\mathrm{CO}_{2}$ for each of the ocean basins. Surface values range from about 45 to $60 \mu \mathrm{mol} \mathrm{kg} \mathrm{kg}^{-1}$. The deepest penetrations are observed in areas of deep water formation, such as the North Atlantic, and intermediate water formation, such as $40-50^{\circ} \mathrm{S}$. Integrated water column inventories of anthropogenic $\mathrm{CO}_{2}$ exceed 60 moles $\mathrm{m}^{-2}$ in the North Atlantic (Figure 9). Areas where older waters are upwelled, like the high-latitude waters around Antarctica and Equatorial Pacific waters, show relatively shallow penetration. Consequently, anthropogenic $\mathrm{CO}_{2}$ inventories are all less than 40 moles $\mathrm{m}^{-2}$ in these regions (Figure 9).

Data-based estimates indicate that the oceans have taken up approximately $105 \pm 8 \mathrm{Pg} \mathrm{C}$ since the beginning of the industrial era. Current global carbon models generally agree with the total inventory estimates, but discrepancies still exist in the regional distribution of the anthropogenic inventories. Some of these discrepancies stem from deficiencies in the modeled circulation and water mass formation. There are also a number of assumptions in the data-based approaches regarding the use of constant stoichiometric ratios and time-invariant air-sea disequilibria that may be inadequate in some regions. These are all areas of current research. Anthropogenic estimates should continue to converge as both the models and the data-based approaches are improved with time.

\section{Conclusions}

As $\mathrm{CO}_{2}$ continues to increase in the atmosphere, it is important to continue the work begun with the Global Survey of $\mathrm{CO}_{2}$ in the Ocean. Because $\mathrm{CO}_{2}$ is an acid gas, the uptake of anthropogenic $\mathrm{CO}_{2}$ consumes carbonate ions and lowers the $\mathrm{pH}$ of the ocean. The carbonate ion concentration of surface seawater in equilibrium with the atmosphere will decrease by about $30 \%$ and the hydrogen ion concentration will increase by about $70 \%$ with a doubling of atmospheric $\mathrm{CO}_{2}$ from pre-industrial levels (280 to $560 \mathrm{ppm}$ ). As the carbonate ion concentration decreases, the buffering capacity of the ocean and its ability to absorb more $\mathrm{CO}_{2}$ from the atmosphere is diminished. Over the long term (millennial time scales) the ocean has the potential to absorb as much as $85 \%$ of the anthropogenic $\mathrm{CO}_{2}$ that is released into the atmosphere. Because the lifetime of fossil fuel $\mathrm{CO}_{2}$ in the atmosphere ranges from decades to centuries, mankind's reliance on fossil fuel for heat and energy will continue to have a significant effect on the chemistry of the earth's atmosphere and oceans and therefore on our climate for many centuries to millennia.

Plans are being formulated in several countries, including the United States, to establish a set of repeat sections to document the increasing anthropogenic inventories in the oceans. Most of these sections will follow the lines occupied during the WOCE Hydrographic Programme on which JGOFS investigators made $\mathrm{CO}_{2}$ survey measurements. The current synthesis effort will provide an important baseline for assessment of future changes in the carbon system. The spatially extensive information from the repeat sections, together with the temporal records from the time-series stations and the spatial and temporal records available from automated surface $\mathrm{pCO}_{2}$ measurements on ships of opportunity, will greatly improve our understanding of the ocean carbon system and provide better constraints on potential changes in the future. 


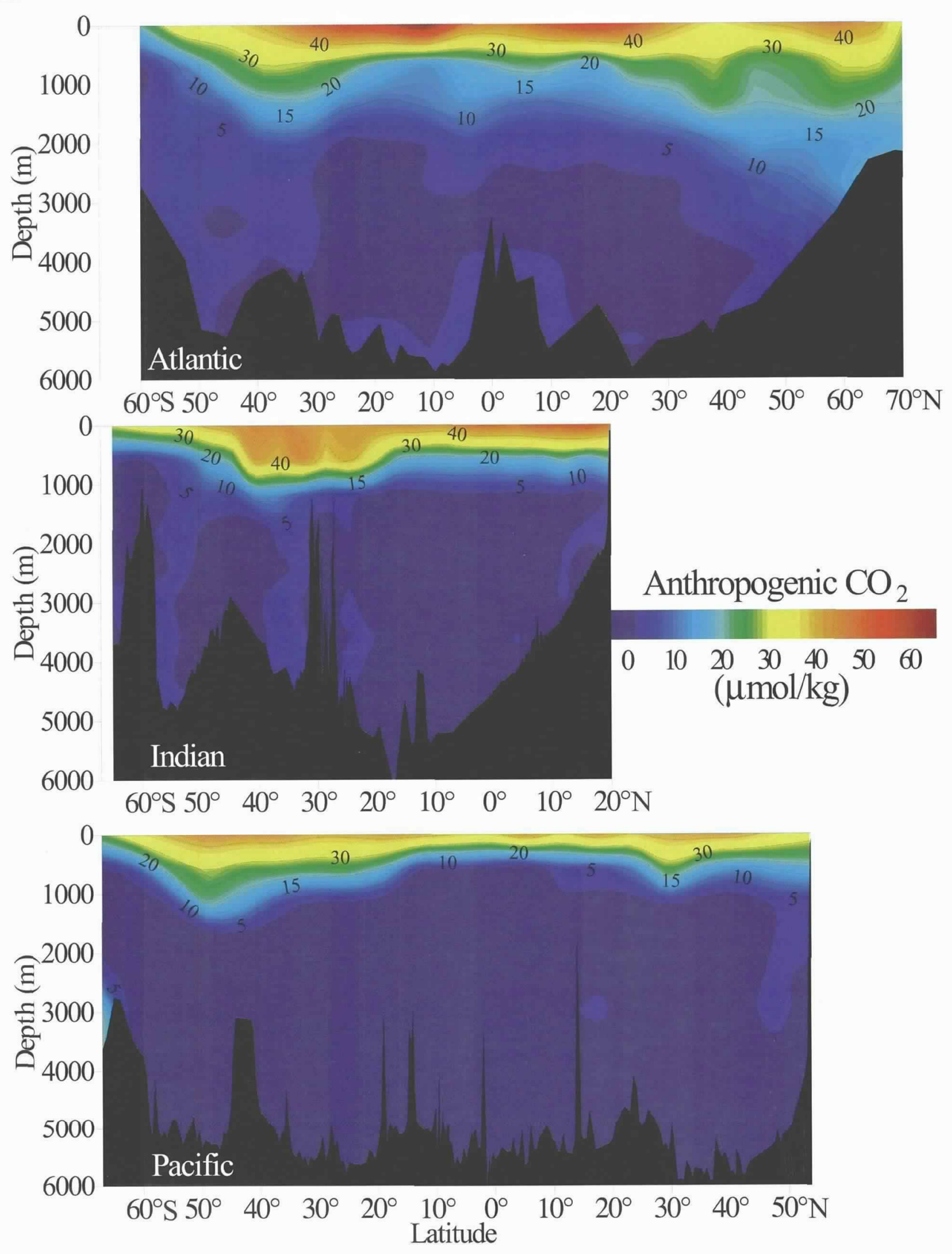

Figure 8. Zonal mean distributions of estimated anthropogenic $\mathrm{CO}_{2}$ concentrations (in units of $\mu$ mol $\mathrm{kg}^{-1}$ ) along north-south transects in the Atlantic, Indian and Pacific oceans. The Pacific and Indian Ocean data are from the Global $\mathrm{CO}_{2}$ Survey (this study), and the Atlantic Ocean data are from Gruber (1998). 


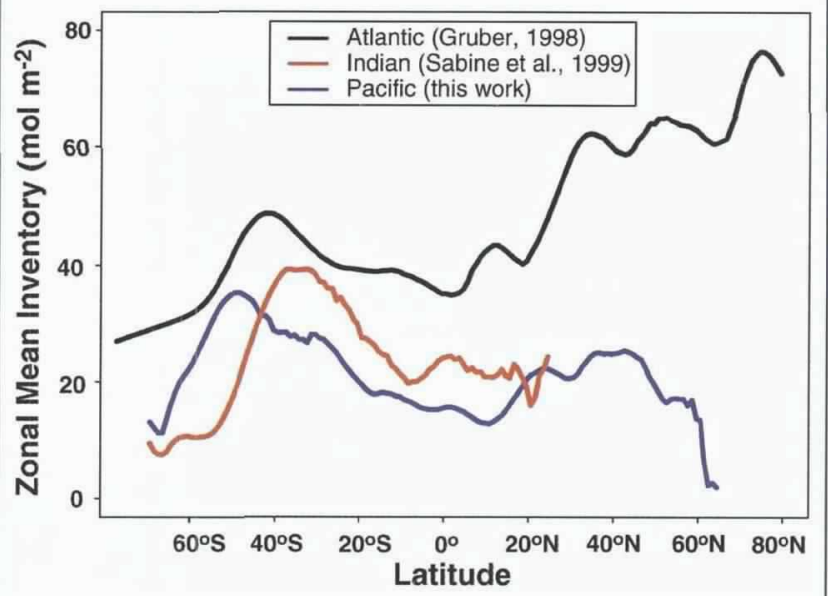

Figure 9. Zonal mean anthropogenic $\mathrm{CO}_{2}$ inventories (in units of moles $\mathrm{m}^{-2}$ ) in the Atlantic, Indian and Pacific oceans.

\section{Acknowledgements}

The authors are grateful to the members of the $\mathrm{CO}_{2}$ Science Team and the JGOFS and WOCE investigators for making their data available for this work. We thank Lisa Dilling of the National Oceanic and Atmospheric Administration (NOAA) Office of Global Programs, Don Rice of the National Science Foundation and Mike Riches of the Department of Energy (DOE) for their efforts in coordinating this research. This work was supported by DOE and NOAA as a contribution to the U.S. JGOFS Synthesis and Modeling Project (Grant No. GC99-220) and by grants to Taro Takahashi from NSF (OPP-9506684) and NOAA (NA16GP01018). This publication was supported by the Joint Institute for the Study of the Atmosphere and Ocean (JISAO) under NOAA Cooperative Agreement \#NA67RJO155, Contribution \#832, and \#2331 from the NOAA/Pacific Marine Environmental Laboratory. This is U.S. JGOFS Contribution Number 683.

\section{References}

Atlas of Surface Marine Data, 1994: CD-ROM NODC56, Ocean Climate Laboratory, NOAA.

Bates, N.R., 2001: Interannual variability of oceanic $\mathrm{CO}_{2}$ and biogeochemical properties in the Western North Atlantic subtropical gyre. Deep-Sea Res. II, 48(8-9), 1507-1528.

Battle, M., M.L. Bender, P.P. Tans, J.W.C. White, J.T. Ellis, T. Conway and R.J. Francey, 2000: Global carbon sinks and their variability inferred from atmospheric $\mathrm{O}_{2}$ and $\delta^{13} \mathrm{C}$. Science, 287, 2467-2470.

Brewer, P.G., 1978: Direct observation of oceanic $\mathrm{CO}_{2}$ increase. Geophys. Res. Lett., 5, 997-1000.

Chen, C.T. and F.J. Millero, 1979: Gradual increase of oceanic $\mathrm{CO}_{2}$. Nature, 277, 205-206.

Feely, R.A., R. Wanninkhof, T. Takahashi and P. Tans, 1999: The influence of the equatorial Pacific contri- bution to atmospheric $\mathrm{CO}_{2}$ accumulation. Nature, 398, 597-601.

GLOBALVIEW- $\mathrm{CO}_{2}$ : Cooperative Atmospheric Data Integration Project - Carbon Dioxide, 2000. CDROM, NOAA CMDL, Boulder, CO. Also available on Internet via anonymous FTP to ftp.cmdl.noaa.gov, Path: ccg/co2/GLOBALVIEW.

Gruber, N., J.L. Sarmiento and T.F. Stocker, 1996: An improved method for detecting anthropogenic $\mathrm{CO}_{2}$ in the oceans. Global Biogeochem. Cycles, 10, 809-837.

Gruber, N., 1998: Anthropogenic $\mathrm{CO}_{2}$ in the Atlantic Ocean. Global Biogeochem. Cycles, 12, 165-191.

Inoue, H.Y., H. Mastueda, M. Ishii, K. Fushimi, M. Hirota, I. Asanuma and Y. Takasugi, 1995: Longterm trend of the partial pressure of carbon dioxide $\left(\mathrm{pCO}_{2}\right)$ in surface waters of the western North Pacific 1984-1993. Tellus, 47B, 391-413.

Keeling, C.D. and T.P. Whorf, 2000: Atmospheric $\mathrm{CO}_{2}$ concentrations-Mauna Loa Observatory, Hawaii, http:://cdiac.esd.ornl.gov/npds/npd001.html, Carbon dioxide Information and Analysis Center, Oak Ridge, TN.

Keeling, R., S.C. Piper and M. Heinmann, 1996: Global and hemispheric $\mathrm{CO}_{2}$ sinks deduced from changes in atmospheric $\mathrm{O}_{2}$ concentration. Nature, 381, 218221.

Liss, P.S. and L. Merlivat, 1986: Air-sea gas exchange rates: Introduction and synthesis. In: The Role of AirSea Exchange in Geochemical Cycling. P. BuatMenard, ed., Reidel, Boston, 113-129.

Nightingale, P.D., G. Malin, C.S. Law, A.J. Watson, P.S. Liss, M.I. Liddicoat, J. Boutin and R.C. UpstillGoddard, 2000: In situ evaluation of air-sea gas exchange parameterizations using novel conservative and volatile tracers. Global Biogeochem. Cycles, 14, 373-387.

Sabine, C.L. and R.A. Feely, 2001: Comparison of recent Indian Ocean anthropogenic $\mathrm{CO}_{2}$ estimates with a historical approach. Global Biogeochem. Cycles, 15(1), 31-42.

Sarmiento, J.L., R. Murnane and C. LeQuere, 1995: Airsea $\mathrm{CO}_{2}$ transfer and the carbon budget of the North Atlantic. Philos. Trans. R. Soc. Lond. (B Biol. Sci.), 348, 211-219.

Siegenthaler, U. and J.L. Sarmiento, 1993: Atmospheric carbon dioxide and the ocean. Nature, 365, 119-125.

Takahashi, T., S.C. Sutherland, C. Sweeney, A. Poisson, N. Metzl, B. Tillbrook, N. Bates, R. Wanninkhof, R.A. Feely, C. Sabine, J. Olafsson and Y. Nojiri, 2001: Global sea-air $\mathrm{CO}_{2}$ flux based on climatological surface ocean $\mathrm{pCO}_{2}$, and seasonal biological and temperature effects, Deep-Sea Res. I, in press.

Wanninkhof, R., 1992: Relationship between gas exchange and wind speed over the ocean. J. Geophys. Res., 97, 7373-7381.

Wanninkhof, R. and W.M. McGillis, 1999: A cubic relationship between gas transfer and wind speed. Geophys. Res. Lett., 26, 1889-1893.

Wanninkhof, R., S. Doney, T. Takahashi and W. McGillis: The Effect of Using Time-Averaged Winds on Regional Air-Sea $\mathrm{CO}_{2}$ Fluxes. In: Gas Transfer at Water Surfaces. M. Donelan, W. Drennan, E. Saltzman and R. Wanninkhof, eds., AGU, Washington, in press. 